\title{
The Factors Effect Purchase Decision of Brand X Pump in PT XYZ
}

\author{
Ririn Wulandari ${ }^{1}$, Aulia Wisuda Muharram ${ }^{2}$ \\ \{ririn.wulandari@mercubuana.ac.id ${ }^{1}$,wisudaulia@gmail.com² ${ }^{2}$, \\ Universitas Mercu Buana, Jakarta, Indonesia ${ }^{12}$
}

\begin{abstract}
Established in 1980, PT XYZ is the first pump manufacturer in Indonesia. Many companies have recognized the advantages of $\mathrm{X}$ brand pumps in terms of quality. However, along with the times, it turns out that the $\mathrm{X}$ brand pump has not been able to become the market leader in the pump industry market, especially in direct sales which is one of the sales segments in PT XYZ which is the Japanese target market. This research aims to examine and analyze the effect of variable brand image, product quality, product price, and delivery time on the purchase decision of brand X pump in PT XYZ. This statistic parametric study use method a multiple regression in which the data processed by the SPSS program. The population has been identified, namely 62 customers, which are Japanese companies in Indonesia that have purchased pump brand $\mathrm{X}$ for their own needs from PT XYZ. The determination of the number of samples used in this study with the census method proposed. The results of this study indicate that the variables of brand image, product quality, price, and delivery time have a significant and positive effect on purchasing decisions, jointly and partially.
\end{abstract}

Keywords: brand image, product quality, price perception, delivery time

\section{Introduction}

PT XYZ is a joint venture manufacturing company between a Japanese $\mathrm{X}$ brand pump company and a local Indonesian company. Established in 1980, PT XYZ can be said to be the first pump manufacturer in Indonesia to have its own factory, especially for metal casting or casting technology. Since its establishment, PT XYZ has contributed to fulfilling the needs of pumps for companies in the industrial sector in particular, both the manufacturing industry, the electrical assembly industry, the oil and gas industry and in collaboration with the government, especially the Ministry of Agriculture, in providing pumps needed in agricultural activities [1].

With PT XYZ's experience for nearly 40 years, many companies have recognized the advantages of $\mathrm{X}$ brand pumps in terms of quality. However, along with the times, it turns out that the $\mathrm{X}$ brand pump has not been able to become the market leader in the pump industry market, especially in direct sales which is one of the sales segments in PT XYZ which is the Japanese target market. companies in Indonesia as customers, PT XYZ has not been able to dominate its market because in the last 6 years from 2013 to 2018 the $\mathrm{X}$ brand pump is only in the number 2 position behind its competitors. 1 brand that is still the market leader [1]. This company must have a movement to seek improvements so that they can grow to dominate that market share. 
In addition, this company experienced a decline in customer satisfaction scores from 2017 to 2018, particularly in product quality, product prices, and delivery times [1]. Product quality decreased from $80.97 \%$ to $80.00 \%$, product prices from $7.50 \%$ to $76.67 \%$, then the delivery time from $76.67 \%$ to $75.69 \%$. However, if we look the sales results have increased from 2017 to 2018, from IDR 34,699,075,443 to IDR 46,727,189,288. A contradictory situation exists, and it seems like an interesting phenomenon where the points given by a customer about satisfaction decrease but actual sales increase [1]. This raises questions about the factors that affect the company performance or that can drive consumer decisions to buy. If left unchecked and the cause is not found, it is likely that it will affect the sales performance of PT XYZ in the future.

Previous research has shown that there are factors that influence purchasing decisions. Price and product quality influence customer purchasing decisions (Adawiyah, 2019 [2]; Barata et al, 2017 [3]; Tamunu and Tumewu, 2014 [4]). Brand image has an impact on the consumer's purchase decisions (Sallam, 2014) [5]. Product price affects customer purchasing decisions (Hustic and Greguree, 2015) [6]. Brand image, quality, and product prices affect customer purchasing decisions (Susanto, 2016) [7]. Quality does impact the purchase decision which agrees with Baltas \& Argouslidis (2007) at AlHuwaishel and Al-Meshal (2018) [8]. Brand image, price, and promotion have a significant and positive influence on customer purchases (Sudaryanto et al, 2019 [9]), perceived price and perceived quality have a significant effect on consumer buying decision (Lalujan, Pengemanan, and Tumbuan, 2016) [19], brand image and price perception have a positive and significant impact on purchase decision (Umbula, Mawuntu, and Potolau, 2019) [20] In addition, delivery time also has an influence on customer purchasing decisions (Kenedy and Kundu, 2018 [10]). On the other hand, the variables of timeliness, delivery of goods, and customer trust have a significant effect on customer satisfaction (Aminah et al, 2017 [11]).

Furthermore, a preliminary survey was conducted to determine the considerations underlying the respondents in making purchase decisions. The survey was conducted on 35 correspondents, presenting 12 variables. The survey results show that the 6 most preferred variables are: product quality, brand image, delivery time, post-sales service, and previous user experience.

Based on the results of previous research, preliminary surveys, as well as the factors assessed in the annual company survey, thus, the factors tested in this study are determined as independent variables that affect the dependent variable, namely the influence of the variable product quality, brand image, product price, and duration of product delivery (delivery time), on purchase decisions. The purchase decision according to Kotler (2013) in Ameliya (2018) [12] is a stage of the purchase decision-making process, where consumers actually make purchases. According to Swastha and Handoko (2008) [13], purchasing decisions are a process of determining whether to buy or not based on several factors of consideration.

\section{Research Method}

The analytical method used in this study is quantitative analysis with multiple regression using the SPSS tool. The population has been identified, namely 62 customers, which are Japanese companies in Indonesia that have purchased pump brand $\mathrm{X}$ for their own needs from PT XYZ. The determination of the number of samples used in this study with the 
census method proposed by Sugiyono (2013) [18], namely sampling type is a technique of determining the sample when all members of the population are used as samples and another term for saturated sample is census. But the feedback from the given questionnaires are only 54 respondents. Questionnaires are sent via email to purchasing decision-makers in the Purchasing or Procurement Division.

\section{Results and Discussion}

$83 \%$ of respondents are large companies, the remaining $17 \%$ are service companies and others. In addition, the average company has been established for a long time, namely before 2000. Even, 37\% of the respondent companies that were established before 1990. The number of employees of all the respondent companies is over 100 people. There are less than 100 people as much as $2 \%$, the employees are between $100-300$ people as much as $41 \%$, the employees are between 300-500 people as many as 15\%, the employees are 500-1000 people as many as $20 \%$. The results of the validity and reliability tests show that all data representing the variables are valid and reliable. Besides that, it meets the standard of normality, does not occur multicollinearity, and does not occur heterogeneity. Thus, the existing data can be processed further.

The results of the F test show that the variables of product quality, brand image, time of delivery of goods, and prices together have a significant and positive effect on purchasing decisions. The $\mathrm{R} 2$ value of $59.2 \%$ indicates that the $\mathrm{Y}$ variable can be explained by changes in the variables X1, X2, X3, and X4 of 59.2\%. Meanwhile, the remaining $40.8 \%$ is explained by other factors outside the model.

Table 1. Simultaneous test results F

\begin{tabular}{|c|c|c|c|c|c|c|}
\hline \multicolumn{7}{|c|}{ ANOVA $^{a}$} \\
\hline Model & & $\begin{array}{l}\text { Sum of } \\
\text { Squares }\end{array}$ & df & Mean Square & $\mathbf{F}$ & Sig. \\
\hline \multirow[t]{3}{*}{1} & Regression & 26.430 & 4 & 6.607 & 17.758 & $0.000^{b}$ \\
\hline & Residual & 18.232 & 49 & 0.372 & & \\
\hline & Total & 44.662 & 53 & & & \\
\hline
\end{tabular}

The $\mathrm{t}$ test results produce the following equation: $\mathrm{Y}$ (purchase decision) $=-1.365+0.325$ $\mathrm{X} 1$ (brand image) $+0.27 \mathrm{X} 2$ (product quality) $+0.428 \mathrm{X} 3$ (product price) $+0.266 \mathrm{X} 4$ (delivery time).

Table 2. Result of t-test

\begin{tabular}{|c|c|c|c|c|c|c|}
\hline & \multirow{2}{*}{ Model } & \multicolumn{2}{|c|}{$\begin{array}{l}\text { Unstandardized } \\
\text { Coefficients }\end{array}$} & \multirow{2}{*}{$\begin{array}{c}\text { Standardized } \\
\text { Coefficients } \\
\text { Beta }\end{array}$} & \multirow{2}{*}{$t$} & \multirow{2}{*}{ Sig. } \\
\hline & & B & $\begin{array}{c}\text { Std. } \\
\text { Error }\end{array}$ & & & \\
\hline \multirow{5}{*}{1} & (Constant) & -1.365 & 0.778 & & -1.754 & 0.086 \\
\hline & Brand Image (X1) & 0.325 & 0.111 & 0.293 & 2.917 & 0.005 \\
\hline & Quality Product (X2) & 0.270 & 0.108 & 0.237 & 2.508 & 0.016 \\
\hline & Price (X3) & 0.428 & 0.093 & 0.449 & 4.629 & 0.000 \\
\hline & Delevery Time (X4) & 0.266 & 0.099 & 0.252 & 2.688 & 0.010 \\
\hline
\end{tabular}


In the table above the sig value of variable $\mathrm{X} 1=0.005<0.05$ so that means this independent variable has a positive and significant effect on variable $\mathrm{Y}$. The higher $\mathrm{X} 1$, the higher Y. And vice versa. In the table above, the sig value of variable X2 $=0.016<0.05$ so that means this independent variable has a positive and significant effect on variable $Y$. The higher X2, the higher Y. And vice versa. In the table above the sig value of the variable X3 $=0.000<0.05$ so that means this independent variable has a positive and significant effect on variable $\mathrm{Y}$. The higher $\mathrm{X} 3$, the higher $\mathrm{Y}$. And vice versa. In the table above the sig value of the variable $\mathrm{X} 4=0.010<0.05$ so that means this independent variable partially has a positive and significant effect on variable Y. The higher X4, the higher Y. And vice versa.

Table 3. Correlation between variables

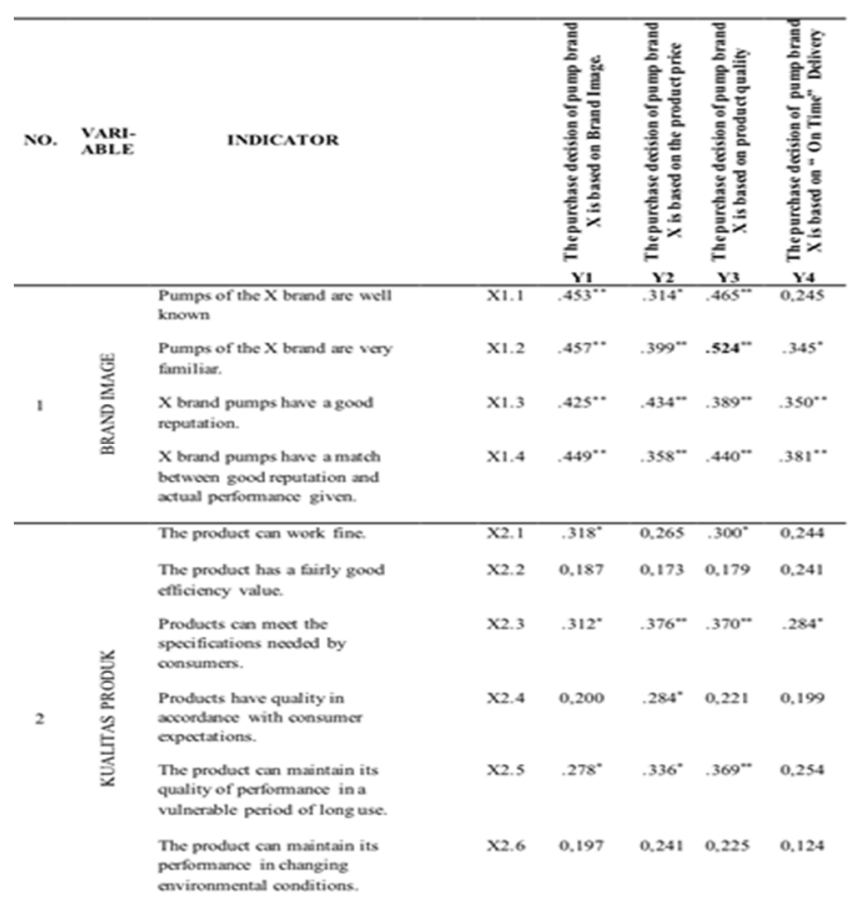

This research shows that the brand image variable has a significant and positive effect on purchasing decisions, with an effect of $32.5 \%$. This means that if there is an increase in recognition and trust in the brand image by $100 \%$, there will be an increase in purchasing decisions by $32.5 \%$. These results are consistent with previous research conducted by Susanto (2016) [7], Amron (2018) [14], and Sudaryanto; Subagio; Awaliyah; Wulandari; and Hanum (2019) [9].

However, there is a contradiction with the results of the study which states that brand image has no effect on Adawiyah's purchasing decisions (2019) [2]. In the indicator brand image variable with the highest correlation value is $\mathrm{X} 1.2$, namely, pump brand $\mathrm{X}$ is very familiar. The strength of this brand image needs to be maintained by improving quality and making product innovations and service innovations so that the $\mathrm{X}$ brand pump can always meet the changing needs of consumers. The t-test results show that the variable product quality has a significant and positive effect on purchasing decisions, with an effect of $27 \%$. This means that if there is an increase in recognition and trust in product quality by $100 \%$, 
there will be an increase in purchasing decisions by $27 \%$. This result is in accordance with previous research conducted by Tamunu and Tumewu, 2014) [4]; Susanto, 2016 [7]; Brata; Husaini; and Ali, 2017 [3]; Anggita and Ali, 2017 [15].

In the product quality variable, there is one indicator that has the highest correlation value among other indicators of purchasing decisions, namely the X2.8 indicator, which states that the product is chosen because of the perceived quality of its country of origin (Japan). This means that until now the perception of the quality of a product is strongly influenced by the perception of the quality of the country of origin. This shows that Japanese products are known to have good quality.

The t-test results show that the variable product price has a significant and positive effect on purchasing decisions, with an effect of $42.8 \%$. This means that if there is an increase in perception and trust in prices by $100 \%$, there will be an increase in purchasing decisions by $42.8 \%$. This is in accordance with the results of previous researchers, including Tamunu and Tumewu, 2014 [4], Susanto, 2016 [7], Anggi, 2016 [16], Brata; Husaini; and Ali, 2017 [3], Ameliya, 2018 [12], Amron, 2018 [14], Albari and Safitri, 2018 [17], and Sudaryanto; Subagio; Awaliyah; Wulandari; and Hanum, 2019 [9].

In the price perception variable, there is one indicator, X3.2, which states that the price of the product is more affordable than the average price of competing brands which is the most strongly connected to purchasing decisions. This condition is really very, very important for PT XYZ regarding pump brand $\mathrm{X}$, because in the minds of customers the price given still tends to have a fairly competitive price compared to competitors, so it becomes a strong consideration in deciding to purchase pump brand $X$.

PT XYZ must really maintain the perception of the price of the pump brand $\mathrm{X}$ to remain in the perception of price affordability compared to competing brands in the minds of customers. Product X's competitive price is related to several other divisions. The thing that needs to be considered is the determination of high-quality suppliers that have competitive prices. Other than that. It needs to be supported by the Engineering division related to the Research and Development process for the products to be sold so that both in terms of design and material selection are made as efficiently as possible without reducing the quality that will be produced.

Also, the role of the Production Planning and Inventory Control (PPIC) division is necessary for formulating their production processes so that they have an effective and efficient lead time related to the production completion time, as well as the role of Sales and Marketing in determining the profit and selling price that will be given to customers so that prices still within purchasing power range consumer and can continue to compete with competitors.

The t-test results show that the delivery time variable has a significant and positive effect on purchasing decisions, with an effect of $26.6 \%$. This means that if there is an increase in delivery speed by $100 \%$, there will be an increase in purchasing decisions by $26.6 \%$. This is in accordance with the results of previous research that the delivery time has an effect on purchasing decisions (Kenedy and Kundu, 2018 [10]; Aminah; Rafani; and Hariyani, 2017 [11]).

From the results of the indicator correlation analysis, it was found that the X4 variable or the delivery time variable had one indicator whose correlation was quite strong among other indicators of purchasing decision variables, namely the X4.2 indicator which stated that the product was delivered in accordance with the estimated delivery time given. Based on this, the management of PT XYZ needs to maintain a commitment between the delivery time that has been promised to customers and the realization of the delivery time made. This means 
that whether or not this commitment is maintained will have a big impact on customers, especially regarding the value of trust they will give to PT XYZ. On the other hand, the results of this study provide input for similar companies in order to penetrate customers and place their products in a better perception of delivery time commitments.

\section{Conclusions}

The results of this study indicate that the variables of brand image, product quality, price, and delivery time have a significant and positive effect on purchasing decisions, jointly and partially. This answers the problems and phenomena that occur, where there is a decrease in satisfaction with product quality, price, and delivery time, on the other hand, there is an increase in company performance. This condition, particularly the decline in product quality satisfaction, price, and delivery time, is still reinforced by a strong brand image, particularly regarding consumer perceptions that products produced by Japanese companies are of good quality and can be accounted for. So even though the results of this study, show that product quality, price, and delivery time have an effect on purchasing decisions, in fact, they feel less satisfied. But, in this case, consumers still consider the brand image factor, so what happens is consumers still choose and decide to buy product $X$, with an increase in sales, despite experiencing dissatisfaction with some of these factors.

Further researchers can develop this research by adding independent variables, including after-sales service, or other variables, because the R2 value of $59.2 \%$ indicates that the $\mathrm{Y}$ variable can be explained by changes in the X1, X2, X3, and X4 variables. Meanwhile, the remaining $40.8 \%$ is explained by other factors outside the model.

\section{References}

[1] Company Profile, PT XYZ, Depok, Indonesia, 2019.

[2] Adawiyah, S. R. "The Effect of Price Perception, Product Quality, and Brand Image on Purchase Decision of Camera Nikon Product," Mercu Buana University. Jakarta, 2019.

[3] Brata, B. H., Husani, B., and Ali, H., "The influence of Quality Products, Price, Promotion, and Location to Product Purchase Decision on Nitchi at PT Jaya Swarsa Agung in Central Jakarta", Saudi Journal of Business and Management Studies. vol-2, Iss-4B:433-44, April. 2017.

[4] Tamunu, M. \& Tumewu, F., "Analyzing The Influence of Price and Product Quality on Buying Decision Honda Matic Motrcycle in Manado", Journal EMBA, vol. 2: 1255-1263, September. 2014.

[5] Sallam, M. A, "The Effects of Brand Image and Brand Identification on Brand Love and Purchase Decision Making: The Role of WOM", International Business Research, vol. 7, no. 10, September. 2014.

[6] Hustic, I. \& Greguree, I., "The Influence of Price on Customer's Purchase Decision”, Central European Conference on Information and Intelligent System, pp-1-6, September. 2015.

[7] Susanto, H, "The Effect of Brand Image, Product Quality, and Price toward Purchase Decision," Muhammadiyah University of Surakarta, 2015.

[8] Al-Meshal, S. A \& Al-Huwashel, N. S., "The Impact of Perceived Value, Quality, and Loyalty on Purchase Decision in The Accessories Department: Study on Saudi Females", British Journal of Marketing Studies, vol. 6, no. 4, pp. 21-31. September, 2018.

[9] Sudaryanto; Subagio, A. N., Awaliyah, I. N., Wulandari, D., \& Hanim, A., "Influence of Brand Image, Price, and Promotion on Consumer's Buying Decision of Fast Moving 
Consumers Goods with culture as a moderating variable in Basmallah Retail Store in Indonesia", International Journal of Scientific and Technology Research, vol. 8, no. 3. March, 2019.

[10] Kennedy, E. N. \& Kundu, G. K., "Influence of Delivery Charges and Time on Online Purchase Decision”, International Journal of Pure and Applied Mathematics, vol. 118, no. 18: 4393-4404, 2018.

[11] Aminah, Rafani, Y. \& Hariyani., "Analysis of the Influence of Factors on Timeliness of Goods Delivery and Customer Trust on Customer Satisfaction (Case Study at PT Jalur Nugraha Ekakurir (JNE) Pangkal Pinang)", Progressive Scientific Journal of Business Management, vol. 17, no. 2, September, 2017

[12] Ameliya, M. "Analysis The Influence of Quality, Price, and Product Completeness on Purchase Decision of Heattech T-Shirt Product," Mercu Buana University, 2018.

[13] Swastha, B and Handoko, H., "Marketing Management, Analysis Consumer Behaviour", BPFE, 2008 .

[14] Amron, A, "The Influence of Brand Image, Design, Feature, and Price on Purchasing Decision of Apple iOS Smartphone in Surakarta", The International Journal of Social Sciences and Humanities Invention, vol. 5, no. 12, pp. 5187-5191, 2018.

[15] Anggita, R. and Ali, H., "The influence of Product Quality, Service Quality, and Price to Purchase Decision of SGM Bunda Milk", Scholars Bulletin. vol-3, Iss-6: 261-272, 2017.

[16] Anggi, A. A., "Analysis The Influence of Price, Service, and Product Quality on Purchase Decision of Electronics Tools in Ardha Electonic Shop," Muhammadiyah University of Surakarta, 2016

[17] Albari \& Safitri, I., "The influence of Product Price on Consumer's Purchasing Decision", Review of Integrative Business and Economics Research, vol. 7, no. 2, pp-328-337, 2018.

[18] Sugiyono, "Metode Penelitian Kuantitatif, Kualitatif, dan R \& D", Bandung, CV Alfabeta, 2013.

[19] Lalujuan, D. I. O., Pengemanan, S. S., and Tumbuan, W. J. F. A. "Analyzing the Influence of Brand Image, Perceived Price, and Perceived Quality on Consumer Buying Decision of Low Cost Green Car ( Case Study of : Astra Toyota Agya At Manado)", Jurnal Berkala Ilmiah Efisiensi, vol. 16, no. 04, pp. 145-155, 2016.

[20] Umbola, F., Mawuntu, P., and Potolau, M., "The Influence of Brand Image and Price Perception on Purchase Decisions", Journal Entrepreneurship and Entrepreneur, vol. 8, no. 2, pp. 16-21, 2019. 